\title{
Tertiary students' perceptions of hospitality careers in Vietnam
}

\author{
Anh Hai Le*, Helen Klieve and Christine V. McDonald
}

*Correspondence:

leah.le@griffith.edu.au

School of Education \&

Professional Studies, Griffith

University, Room 5.46

M10, Mt Gravatt Campus,

Brisbane Qld 4111, Australia

\begin{abstract}
Background: Hospitality personnel are often prepared through vocational education and training (VET) and higher education (HE) providers, taking different emphases. In Vietnam's hospitality workplaces, HE graduates compete with VET graduates for the same basic operational positions, with limited managerial positions available. Given the different educational pathways taken for similar career opportunities in the current labour market, it is important to understand students' views of hospitality workplaces as their future career environment. The aim of this study is to identify and examine underlying factors that determine tertiary students' overall career perceptions in hospitality in the Vietnamese context.
\end{abstract}

Methods: A quantitative study utilising an online survey was conducted with 234 hospitality students from different higher education institutes and VET colleges in the South of Vietnam. Chi squared statistics and logistic regression were performed to assess the views and significant educational level differences.

Results: The analyses show marked differences in views between the HE and VET participants on several aspects of hospitality workplaces, including pay/promotion opportunities, management, and commitment to the industry. The HE participants appeared less positive, and indicated a lower commitment to a future in the hospitality industry.

Conclusion: The results of this study have important implications for various stakeholder groups. Students' negative perceptions, associated with their internship experiences in different aspects of hospitality workplaces, currently appear to result in detrimental consequences for HE students, with many not planning on remaining in the hospitality sector. This has both short-term and long-term implications for hospitality employers, hospitality educational providers, and Vietnam's HE system.

Keywords: Higher education, Tertiary education, Hospitality education, Hospitality industry, Workplaces, Student perceptions, Internships, Vietnam

\section{Background}

International hospitality and tourism has been widely recognised as a fast-growing, labour-intensive industry (Korpi and Mertens 2004) that has the potential to make a significant economic contribution to national GDP (Crotti and Misrahi 2015; Truong 2006). The sector has become an increasingly important driver of growth and prosperity for many countries, with a reported contribution of around $9.5 \%$ of the world's GDP, and an employment contribution of one in every 11 jobs in 2013 (Crotti and Misrahi 2015). Although this sector in Vietnam accounts for $4.6 \%$ of GDP, Vietnam is ranked

(c) The Author(s) 2018. This article is distributed under the terms of the Creative Commons Attribution 4.0 International License (http://creativecommons.org/licenses/by/4.0/), which permits unrestricted use, distribution, and reproduction in any medium, provided you give appropriate credit to the original author(s) and the source, provide a link to the Creative Commons license, and indicate if changes were made. 
75th against 141 countries globally, and ranks 15th against the other 23 Asia-Pacific members. This is well below Vietnam's close competitor Thailand, which is currently ranked 35th internationally and 10th in Asia Pacific, with a contribution of 9\% of GDP (Crotti and Misrahi 2015). Human Resources are considered to be a key aspect of the Asia-Pacific region's strategy to develop the travel and tourism sector, which offers possibilities for several countries to improve their position via a high-quality education system (Crotti and Misrahi 2015). Vietnam's overall performance in the area of Human Resources and Labour Market in the Travel and Tourism Competitive Index is 55th-placing Vietnam significantly below the performance of Thailand, ranked 29th internationally.

Within the hospitality area, tertiary education is a major workforce provider for local enterprises, with students prepared through vocational (VET) and higher education (HE) institutions. In preparing students, HE and VET providers have a different emphasis. Vocational colleges/schools place a greater emphasis on specific operational skills targeted to the immediate needs of the industry whereas universities where a greater focus on strategic management strategies, learning how to flexibly cope with the changing skill requirements or the rapid technological advances (Zagonari 2009). However, upon graduation, HE graduates compete with VET graduates for the same basic operational positions (requiring operational skills) with limited managerial positions (requiring strategic skills) available. This situation links to that seen in other developing nations which has looked at the growth of over-education in unskilled jobs, underlined by the weak demand for skilled labour, and slow expansion of education-intensive occupations (Mehta et al. 2013).

Given the different pathways to hospitality careers taken by students in Vietnam, yet very similar career opportunities offered to students in the current labour market, it is particularly interesting to understand how they view the hospitality workplace and how they see theirs as a future career environment. Such perceptions have the potential to inform our understanding on the refinement of education, training and job and also labour market strategies to gain most for the industry. However, little attempt has been made to address various student perceptions according to their tertiary educational level. Therefore, the purpose of this study is to identify and examine underlying factors that determine tertiary students' overall career perceptions, and predict their educational level (VET or HE) in hospitality in the Vietnamese context.

\section{Literature review}

This section will review and discuss research relating to the importance of relationships between the hospitality industry and education as well as the implications of industry internships for stakeholders. The review then concludes with previous research on students' perceptions of hospitality careers, and the industry-education relationship in the Vietnamese context.

\section{Hospitality industry-education relationships}

A large body of research lends support to the significance of hospitality industry-education collaboration (e.g., Barrows and Walsh 2002; Goodman and Sprague 1991; Jayawardena 2001; Littlejohn and Watson 2004; McHardy and Allan 2000; Zopiatis and 
Constanti 2007). Although higher education institutions (HEIs) have maintained their agreement, in principle, with industry regarding the inclusion of internship components in hospitality education programs, questions have been raised regarding the quality of the industry-education relationship (Zopiatis and Constanti 2007). Few studies have addressed the quality of this relationship and the degree to which hospitality programs meet the requirements of industry (Lam and Xiao 2000; Zopiatis and Constanti 2007).

Zopiatis and Constanti (2007) developed a five-GAP model from their investigation of the hospitality industry-education relationship in Cyprus, highlighting issues in the relationship between hospitality educators, students and industry. These gaps include the mismatch between students' expectations whilst enrolled at educational institutions, and their learning experience in terms of academic delivery (Gap 1), between students' expectations and their actual industry experience (Gap 2), between students' expectations of workplaces and the actual operation of hospitality enterprises (Gap 3), between industry requirements and the delivery of educational providers (Gap 4) and between the institution's planned experience and students' actual industry experience (Gap 5). To fully understand the nature of the relationships these five gaps must be examined from the perspectives of all involved, i.e., hospitality industry, students and educators.

As a pioneer in the European hospitality industry, Switzerland has successfully explored the industry-education relationship via the systematic integration of theoretical components and industry internships (Zopiatis and Constanti 2007). The fruitful industry-education relationship has resulted in effectively addressing the five gaps. Since the early 1920s, the development of hospitality educational programs oriented towards industry expectations have been extensively adopted in the hospitality industry worldwide, and this orientation has been recently introduced in Asia (Shariff 2013). In the early 1980s, hospitality educators and industry practitioners agreed internships should be an essential component of hospitality education programs to effectively prepare students for engagement as future industry professionals (Morrison and O'Mahony 2003). The achievement of such programs require a close partnership between the hospitality industry and education providers (Tesone and Ricci 2005; Zopiatis and Constanti 2007). Through this partnership, industry needs can be identified and addressed, through the provision of skilled staff with appropriate educational qualifications (Smith and Cooper 2000). A competitive education system must respond to the needs and expectations of those involved, including industry employers, students, and educational providers (World Tourism Organisation 2004). However, the achievement of such programs is, in many developing countries, still in the early stages of development.

\section{Internships and implications for stakeholders}

Internships realise many benefits for all stakeholders, in a field where occupation-specific skills are critical. For employers, internships provide access to a pool of workers who are academically-trained at a low cost (Beggs et al. 2008), typically enthusiastic and dedicated to the industry, and bring fresh ideas to the workplace (Walo 2001), thus helping to avoid staff turnover (Fell and Kuit 2003). Internships also provide employers with opportunities to screen potential employees prior to making long-term commitments, and to have direct involvement in training future managers (Ju et al. 1998; Petrillose and Montgomery 1997). Employer recruitment processes are facilitated through internships 
by providing a more in-depth assessment of potential employees working as interns than via one-off job interviews (Yiu and Law 2012). Research indicates that interns who undertake graduate positions with the company with whom they completed their internship exhibit greater job satisfaction and more realistic expectations grounded in their experience (Hiltebeitel et al. 2000).

For education providers, internships can strengthen links with industry. This can enhance collaborative research opportunities, raise an institutions' profile, and establish long term working relationships between industry and institutions to optimise future graduate employment opportunities (Bell and Schmidt 1996; Walo 1999). The enhanced link between industry and institutions can lead to improved curriculum provision (Leslie and Richardson 2000), and the credibility of an institution may then be acknowledged by industry via enhanced student performance (Cook et al. 2004). In terms of student recruitment, the inclusion of an internship component can also provide an institution with a competitive advantage as research indicates that parents believe job search upon graduation can be facilitated via previous internship experience (Yiu and Law 2012).

For students, internships provide opportunities to put into practice theoretical concepts learnt in their programs, gain a greater understanding of industry requirements, explore career choices, and develop important hands-on, work-related skills (e.g., Barron 1999; Singh and Dutta 2010; Velde and Cooper 2000). Research on hospitality work internships has predominantly focused on skill development in internships (Maher 2005), with findings indicating that participation contributes towards developing students' managerial skills (Walo 2001), including leadership, human resources, oral and written communication, interpersonal communication, problem solving, teamwork, planning and decision-making (Molseed et al. 2003).

\section{Student perceptions of hospitality careers}

Student attitudes towards working in the hospitality industry are likely to be influenced by their internship experiences. Student motivation and commitment to a hospitality career varies, and is highly dependent on their experiences in workplaces, especially during their industry internships (Aksu and Köksal 2005; Bednarska and Olszewski 2013; Jiang and Tribe 2009; Kusluvan and Kusluvan 2000; Richardson 2010a, b; Wang and Huang 2014), as the benefits of internships support the wider incorporation of these components into hospitality programs (Yiu and Law 2012). Cook et al. (2004) examined HE students' attitudes towards specific elements of an ongoing internship program from 12 colleges and universities in the United States. After the internship, students reported appreciation of their experiences, and stated they had developed enhanced confidence and an improved ability to work with others (Cook et al. 2004). In other research, benefits students perceived from their internship experiences included a better understanding of an organisation's structure and functions, the ability to form realistic career expectations, a wider professional network, an increased ability to adapt to change, and improved leadership skills (Lee 2008). However, all internships do not deliver positive experiences, with a low level of satisfaction reported where students' expectations prior to internships exceed their perceptions on completion of the internship (Lam and Ching 2007; Singh and Dutta 2010). 
Several studies during the 2000s have reported a substantial number of hospitality graduates leave the industry due to low levels of job satisfaction, lack of motivation, and poor working conditions (e.g., Kusluvan et al. 2003; Shin and Lee 2011), accounting for increased staff turnover and attrition of trained personnel in the industry. Kusluvan and Kusluvan (2000) developed a multi-dimensional attitude scale to investigate students' career perceptions of hospitality, and validated their instrument with fourthyear tourism and hotel management students in Turkey. They reported students held negative perceptions towards almost all dimensions of working in hospitality. Richardson (2010a) applied their attitudinal scale in an Australian context, and found that more than $50 \%$ of the surveyed students were contemplating careers outside the industry, with $92 \%$ of these participants citing that such a decision primarily resulted from negative working experiences in the industry. When comparing hospitality students' views at two universities in the United Kingdom and the Netherlands, Jenkins (2001) found that students tended to develop unfavourable attitudes towards the industry as they progressed through their studies. In an Asian context, Jiang and Tribe (2009) investigated Chinese students' attitudes towards working in the hospitality industry and found that these students perceived hospitality professions 'short-lived'. The factors impacting on their attitudes were related to individual characteristics, the nature of hospitality jobs, interactions with tourists, pre-internship practical training, and management practices at the hospitality organisations. These concerns about long-term hospitality careers have implications for different stakeholders with regard to the HE sector and hospitality industry in both China, and elsewhere.

Research in a variety of contexts indicates that industry internships or work experience affects students' career perceptions in a negative manner. Maintaining students' satisfaction with their internship experience has been argued to be of crucial importance (Chen et al. 2009; Fong et al. 2014; Lam and Ching 2007; Singh and Dutta 2010). Therefore, on-going investigation and monitoring of students' views of working in the industry are needed to update and improve educational programs to realise the benefits of internships for students.

\section{Hospitality industry-education relationship in Vietnam}

Hospitality education, while first introduced in Vietnam by three universities during the 1980s, offering limited majors primarily focused on food and beverages (VNAT 2006), is still a developing field. Educational institutions offering hospitality programs at tertiary level continue to grow in number, with 38 institutions identified in 2004 (VNAT 2004), 114 in 2007, and 125 in 2010 (Nguyen and Chaisawat 2011). Despite three decades of operation, Vietnam's tertiary hospitality programs, particularly those at HEIs, have not experienced major improvements in updating program content in terms of meeting industry requirements for work-related skills. A focus on preparing human resources for the hospitality industry in terms of quantity, rather than addressing industry demand for high quality human resources, is an ongoing concern (Nguyen and Chaisawat 2011). Educational quality is a major issue as standards for hospitality HE have not been fully formulated and consistently applied across educational providers (VNAT 2012).

However, research suggests the current education system in Vietnam does not effectively prepare graduates with the necessary skills required to successfully engage in the 
industry, particularly with respect to the skills needed to engage in enterprises with international connections (Bodewig and Badiani-Magnusson 2014). In HE across different disciplines, several constraints have emerged including a mismatch between educational institutions' training approach, and the actual needs of industries, and the poor alignment of program content across different subject areas (Institute of International Education 2004; Oliver 2002) including hospitality (Le et al. 2015; Nguyen and Chaisawat 2011). One identified concern with the HE programs is the high unemployment rates of graduates who are under-prepared in terms of professional knowledge and skills (IIE 2004; Ketels et al. 2010; Oliver 2002).

Attempts to develop and improve the education system are dependent on the integrated response from three primary stakeholders, including government agencies, educational institutions, and industry (Jafari 2002). However, in Vietnam research indicates that cooperation between educational institutions and industry is limited (Ashwill 2010; Bilsland and Nagy 2015; Di Gropello 2008; Ketels et al. 2010; Trinh 2008), resulting in educational institutions' ineffective response to labour market needs (Di Gropello 2011). Also, research indicates minimal initiative support policies to facilitate and encourage greater partnerships between stakeholders (Jafari 2002; Tran 2015). Although internships are considered an important component of hospitality programs, hospitality students in most institutions are advised to proceed with applying for work internships on their own, with institutions only providing administrative support. Interestingly, there are no processes through which hospitality institutions are informed of the work undertaken by students, nor any assessment provided by the workplace involved. This has resulted in a lack of monitoring of the delivery of workplace practices and professional development by students.

Despite having different vocational foci in terms of occupation-specific skills preparation, both VET and HE students are required by their institutions to undertake similar internships in the hospitality industry, preferably in 4-star and 5-star hotel companies, including multinational hotel enterprises.

As in other developing economies, the Vietnamese hospitality sector includes small and medium enterprises (SMEs), as well as high-end hospitality service providers. Additionally, this sector also includes many large, multinational hotel enterprises which are usually positioned at the highest end of the scale in terms of size and prestige, and hold senior positions in the labour market (Fligstein 1996; Podolny 1993). With significant market power and large scale of operation, these organisations are major sources of employment across different skill levels; however, their recruitment policy, primarily directed towards expatriates for the majority of management positions (Fortanier and Van Wijk 2010; Kusluvan and Karamustafa 2001; Mowforth and Munt 2003), offers limited opportunities for indigenous labour force participants. This also limits both potential upskilling for local HE trainees and graduates as they transition from their academic learning environments into industry practice.

Students' perceptions of their employability in the changing context of HE and labour markets has been explored in many studies (e.g., Rothwell and Arnold 2007; Rothwell et al. 2008, 2009; Tomlinson 2008). Findings indicate that students were concerned about the utility of their university qualifications in securing expected employment outcomes. They viewed themselves as being in competition with a growing supply of other 
graduates entering the labour market with similar profiles and aspirations. Due to the global expansion of HE, an increased number of students have been positioned outside, and excluded from, graduate labour market opportunities (Leathwood and O'Connell 2003; Reay et al. 2005). This suggests that hospitality students face challenges in gaining positional advantage in a labour market where academic qualifications are decreasingly valued by employers (Brown et al. 2004). This results in the current situation in Vietnam where graduates at different educational levels are often competing for the same positions in the labour market. It is likely that such patterns of labour market inequality are reinforced by the expansion of $\mathrm{HE}$ and the declining value of academic credentials (Tomlinson 2008).

\section{Methodology}

A quantitative study utilising an online survey was conducted with 234 hospitality students from different higher education institutes (HEIs) and VET colleges in the South of Vietnam. The HEIs and VET colleges selected in this study offer various disciplines/ majors including hospitality-related majors, e.g., hotel and restaurant management.

\section{Instrument}

The survey instrument was adapted from Kusluvan and Kusluvan (2000) "Perceptions and attitudes of undergraduate tourism students towards working in the tourism industry in Turkey", a widely used, multi-dimensional scale. This scale was initially validated with a large sample of Turkish tourism and hotel management students, and further utilised and successfully validated in several studies investigating students' perceptions of working in the hospitality/tourism industry in different contexts including Australia (Richardson 2009, 2010a), United States (Richardson and Thomas 2012), Malaysia (Richardson and Butler 2012), and China (Wang and Huang 2014). Permission was sought and approved by the first author for the scale to be utilised and adapted in this study.

Modifications were made to the original 79-item scale under nine dimensions of hospitality/tourism workplaces for this study. As a first screening step, items with corrected item correlation of less than .4 from the initial study (Kusluvan and Kusluvan 2000) were not included, resulting in 61 items in the modified scale used in the pilot testing phase. This adaptation process resulted in small changes to eight of the nine dimensions, with major changes being made to the first dimension-'Nature of work'-with only three of the original twelve items being included. While this meant that the 'Nature of work' dimension would be weak, this was aligned with the main objective of the survey to gauge students' views on the hospitality workplaces in which they experienced during their internships/internships.

A three-part survey was developed. Table 1 provides a summary of the survey structure, including background details and additional views from participants.

"Background" section sought demographic information about participants including age, gender, current degree enrolled, and reasons for hospitality study. The section consisted of eight questions with a range of closed options. In "Literature review" section, responses to attitudinal items were measured on a 5-point Likert scale assessing agreement, indicating the level of agreement (from $1=$ strongly agree to $5=$ strongly disagree). In "Hospitality industry-education relationships" section, participants were asked to 
Table 1 Summary of the survey structure

\begin{tabular}{lll}
\hline Section & Question groups & Detail \\
\hline 1 & Demographic and background & Age, gender, education institution \\
2 & Views on working in the hospitality industry & $\begin{array}{l}7 \text { subscales: (i) nature of work, (ii) social status, (iii) } \\
\text { industry-person congeniality, (iv) pay/promotion } \\
\end{array}$ \\
& & $\begin{array}{l}\text { opportunities, (v) co-workers, (vi) managers, and (vii) } \\
\text { commitment to the industry }\end{array}$ \\
& Comments & Experiences of working in the industry \\
\hline
\end{tabular}

Table 2 Summary of changes to the modified scale

\begin{tabular}{|c|c|c|c|}
\hline Dimensions & Comments & Changes & $\begin{array}{l}\text { Final scale } \\
\text { (\# of items) }\end{array}$ \\
\hline Nature of work & $\mathrm{n} / \mathrm{a}$ & $\mathrm{n} / \mathrm{a}$ & 2 \\
\hline Social status & $\mathrm{n} / \mathrm{a}$ & $\mathrm{n} / \mathrm{a}$ & 3 \\
\hline Industry-person congeniality & $\begin{array}{l}\text { Not relevant-1 item"Working } \\
\text { in hospitality contradicts to my } \\
\text { religious values" }\end{array}$ & Deleted & 9 \\
\hline Physical working conditions & Not relevant—whole dimension & $n / a$ & 0 \\
\hline $\begin{array}{l}\text { Pay/fringe benefits } \\
\text { Promotion opportunities }\end{array}$ & $\begin{array}{l}\text { Several statements of obvious } \\
\text { and/or similar meaning }\end{array}$ & $\begin{array}{l}3 \text { items deleted } \\
\text { Dimensions combined and } \\
\text { renamed 'Pay/promotion } \\
\text { opportunities' }\end{array}$ & 8 \\
\hline Co-workers & $\mathrm{n} / \mathrm{a}$ & & 9 \\
\hline Managers & $\mathrm{n} / \mathrm{a}$ & & 13 \\
\hline Commitment to the industry & Items with similar meaning & Pairing & 10 \\
\hline
\end{tabular}

share any additional comments regarding their experiences in hospitality workplaces that were not addressed in the survey. This offered an opportunity for participants to provide further details on their experiences.

Translation of the survey using the modified scale was performed using a blind, backtranslation process. A pilot test of the survey was undertaken to reflect on potential problems in the survey, and to make appropriate revisions before the final release. This process also provided a check on the translation process. Electronic copies of the survey using the modified scale were emailed to thirty Vietnamese hospitality students in Vietnam. They were asked to complete the survey and provide feedback on the comprehension and clarification of the items used in the modified scale. Modifications and changes were then made to reflect the feedback provided by the students on the survey. The summary of changes is shown in Table 2 .

The piloting process resulted in the final 54-item scale with seven dimensions: (1) nature of work (2 items), (2) social status (3 items), (3) industry-person congeniality (9 items), (4) pay/promotion opportunities (8 items), (5) co-workers (9 items), (6) managers (13 items), and (7) commitment to the hospitality industry (10 items) (see Appendix). Based on the feedback in the pilot, the questions/statements in dimension 'physical working conditions' were found to be not relevant to the Vietnamese context. The dimensions 'pay/fringe benefits' and 'promotion' in the original scale were combined and labelled 'pay/promotion opportunities' in the questionnaire for this study. Also, several questions/statements in the original scale, after being assessed against contextual 
relevance and linguistic nature, were omitted from the instrument. Examples of modifications/changes include the exempt of items of obvious meaning or commonly known features such as 'Working hours are not suitable for a regular life in the hospitality/tourism industry', or being irrelevant in the Vietnamese context such as 'Working in hospitality contradicts with my religious values'; and pairing similar items such as 'I would not want my son or daughter to study hospitality and work in the hospitality industry' as a result of the pairing of 'I would not want my son to study hospitality and work in the hospitality industry' and 'I would want my daughter to study hospitality and work in the hospitality industry'.

\section{Sampling and procedures}

Criterion-based sampling was applied to identify students who had completed their work internships, and would be well positioned to provide insights into their professional development journey experienced in industry environment. HEIs sampled in this study are profiled in Table 3.

The HEIs selected in this study offer various disciplines/majors including hospitality-related majors, e.g., hotel and restaurant management. As each discipline/major is assigned equal student quota, the annual intake for the hospitality-related major/s of an HEI was estimated from the total annual intake in each institution. For example, OP offered 15 majors with a total annual intake of 2500, which generated approximately 166 enrolments for the major-Hotel and Restaurant Management\|. All the HEIs selected for this study have been operating for approximately 10 years or more. During this time UFM, HSU and NTT were upgraded to university level (offering 4-year bachelor

Table 3 Summary of hospitality-related programs in nine HEls

\begin{tabular}{|c|c|c|c|}
\hline Name of HEls & $\begin{array}{l}\text { Hospitality-related } \\
\text { majors }\end{array}$ & Year of establishment & Estimated annual intake \\
\hline Open University (OP) & $\begin{array}{l}\text { Hotel and restaurant } \\
\text { management }\end{array}$ & 1993 & 166 (2500 for 15 majors) \\
\hline $\begin{array}{l}\text { Ho Chi Minh University of } \\
\text { Foreign Languages and } \\
\text { Information Technolo- } \\
\text { gies (HUFLIT) }\end{array}$ & $\begin{array}{l}\text { Hotel and restaurant } \\
\text { management }\end{array}$ & 1994 & 230 (2300 for 20 majors) \\
\hline Van Lang University (VLU) & Hotel management & 1995 & 138 (2500 for 18 majors) \\
\hline $\begin{array}{l}\text { Ho Chi Minh City Uni- } \\
\text { versity of Technology } \\
\text { (HUTECH) }\end{array}$ & $\begin{array}{l}\text { Hotel management } \\
\text { Restaurant and food ser- } \\
\text { vice management }\end{array}$ & 1996 & 318 (3500 for 22 majors) \\
\hline $\begin{array}{l}\text { Ton Duc Thang University } \\
\text { (TDT) }\end{array}$ & $\begin{array}{l}\text { Hotel and restaurant } \\
\text { management }\end{array}$ & 1997 & 105 (3160 for 30 majors) \\
\hline $\begin{array}{l}\text { Hong Bang University } \\
\text { (HBU) }\end{array}$ & $\begin{array}{l}\text { Hotel and restaurant } \\
\text { management }\end{array}$ & 1997 & 69 (1800 for 26 majors) \\
\hline $\begin{array}{l}\text { University of Finance and } \\
\text { Marketing (UFM) }\end{array}$ & $\begin{array}{l}\text { Hotel management } \\
\text { Restaurant and food } \\
\text { service }\end{array}$ & $\begin{array}{l}2004 \text { (upgraded from } 1976 \\
\text { College) }\end{array}$ & 708 (3900 for 11 majors) \\
\hline Hoa Sen University (HSU) & $\begin{array}{l}\text { Tourism-hotel manage- } \\
\text { ment } \\
\text { Restaurant and food ser- } \\
\text { vice management }\end{array}$ & $\begin{array}{l}2006 \text { (upgraded from } 1991 \\
\text { College) }\end{array}$ & 212 (2230 for 21 majors) \\
\hline $\begin{array}{l}\text { Nguyen Tat Thanh Univer- } \\
\text { sity (NTT) }\end{array}$ & $\begin{array}{l}\text { Hotel management } \\
\text { Restaurant and food ser- } \\
\text { vice management }\end{array}$ & $\begin{array}{l}2011 \text { (upgraded from } 2005 \\
\text { College) }\end{array}$ & 290 (3500 for 24 majors) \\
\hline
\end{tabular}


degrees) from their initial college level (offering 3-year diploma degrees). The hospitality-related programs offered at the HEIs have been well established over the operation period of each institution.

Students in these institutions have easy and convenient access to computers, and as a part of their courses are required to use the internet on a regular basis to access information such as announcements, lecture notes and academic events. Emails are the preferred mode of communication in these institutions. An emailed link to the online survey was considered the most efficient strategy to collect survey responses.

Participants were informed of the purpose of the survey in an invitation email, with instructions provided on completing specific sections throughout the survey. The issue of response rate, critical in the use of surveys, was considered in planning the data collection process. In an environment such as a tertiary institution where students have broad access to, and familiarity with information technology, online surveys are widely used to provide a quick and easy form of data collection, particularly where large numbers of participants are available, or where such participants are located at a geographically broad distance. However, response rates are an important consideration in online survey research with factors such as question length and type, and the personality of the recipients needing consideration (Kaplowitz et al. 2004). The concern about low response rates from e-mail and web-based survey was also raised by Sills and Song (2002), who viewed the combination of web-based surveys and mailed surveys providing a good strategy through which to gain a high response rate. Accessibility is also a recognised issue with access to computers and technological competence (Mertler 2001) an important consideration. For this study, contact was made with staff in each institution to ensure engagement with students was achieved, also providing the capacity to provide reminders to students to enhance response rates. Reminder emails were also sent to encourage survey completion. To assist in the delivery process initial contact with academic coordinators in the target departments/faculties who had regular contact with the identified students was made early in the study seeking assistance in the surveying process. A snowballing technique was also used to further increase the response rate. The students were asked to assist in circulating the link to the survey in other communication channels such as Facebook and personal emails. No mandatory responses were included in the survey, further encouraging participants to complete the survey.

\section{Data analysis}

Descriptive and multivariate analyses were undertaken using SPSS Version 24. The responses to the attitude statements by dimensions were firstly summarised by response pattern with Chi squared statistics used to explore differences between HE and VET student responses. To address multiple test issues, a Bonferroni correction was applied. With 54 items being tested, significance was tested against $\mathrm{p}<.001$ (.05/54 hypotheses) (Cabin and Mitchell 2000) following a check that assumptions were met (i.e. 20\% or less of the cells having expected counts less than 5). The effect size, was also examined using Cramer's V, with interpretation based on Cohen's (1988) guidelines with regard to the $r$ family values, i.e., Cramer's V in this study, which is rarely above .70. These guidelines are based on effect sizes usually found in studies in education and behavioural sciences (Morgan et al. 2013). 
Multivariate analyses were then undertaken to explore student group differences. A Reliability Analysis was undertaken on each dimension, and where appropriate average scores calculated. As the sample size of 253 cases is considered to be fair (Tabachnick et al. 2001), a further assessment of the predictive items by student groups was captured through a logistic regression. Models (i.e., equations) were created for six dimensions. As the reliability for the dimension 'nature of work' was relatively low $(\alpha=.430)$, and given the small number of items in this subscale due to limited inclusion of items from the original scale, this dimension was not included in this analysis.

A binary logistic regression was undertaken to simultaneously explore the possible effect of the different items in each dimension against status as either a VET or HE student and the prediction of this status. This is an appropriate choice given the nature of the data (i.e. categorical predictor and ordinal independent variables). The assumptions of logistic regression (Berry 1993; Field 2013) were checked and met for the data in the study. These assumptions include variable types and large sample size, with very limited multicollinearity among independent variables (Field 2013). The full models containing all predictors were statistically significant with the $p<.001$, indicating that the models were able to provide a predictive measure of group status-whether VET student or HE student. For consistent interpretation, when a significance odds ratio $(\mathrm{OR})<1$, it was inverted, i.e., 1/OR. Results to open comments are not reported in this article. Note that for consistency, the reverse coding used in the reliability assessment was also used in this analysis, thus a low score indicates strong agreement.

\section{Results}

\section{Characteristics of the participants}

Survey responses were received from 253 participants-149 from those in an HE program and 104 in a VET program. The background of participants is summarised in Table 4 . The participants were predominantly female (61.9\%), although some gender difference is seen between programs with a higher proportion of HE students identifying as female (69.8\%) compared to VET students (50.5\%). This gender distribution well represents the overall hospitality workforce which is also predominantly female, and is also similar to that across Vietnamese hospitality HE, which has a ratio of 2:1.

The participants were predominantly aged between 18 and 24 years (91.3\%), the typical age range of tertiary students in Vietnam (Do and Do 2014). Whilst only $4 \%$ of the HE participants were aged between 25 and 30, a slightly higher $14.4 \%$ of the VET participants were in this age group. This representation across age groupings between the two participant groups likely captures participation in tertiary education for both academic preparation (via HE programs), and ongoing vocational development (via VET programs).

All participants had completed industry internships. The greater majority (67.2\%) had 6 months or less experience, while 13\% reported having more than 9 months' work experience in industry. More VET participants (43.3\%) reported completing longer internship periods (6 months or more) than did their HE counterparts (25.5\%).

The participants were asked to indicate the departments/areas in which they had their longest work/internship experience. The major areas in a hospitality enterprise include occupation-specific areas such as front office, food and beverages, kitchen, 
Table 4 Background and demographic characteristics of 253 participants

\begin{tabular}{|c|c|c|c|c|}
\hline Variables & Values & VET (\%) & HE (\%) & Total (\%) \\
\hline \multirow[t]{4}{*}{ Age } & $18-24$ & 85.6 & 95.3 & 91.3 \\
\hline & $25-30$ & 14.4 & 4.0 & 8.3 \\
\hline & $>30$ & .0 & .7 & .4 \\
\hline & Total & 104 & 149 & 253 \\
\hline \multirow[t]{4}{*}{ Gender } & Male & 42.7 & 28.2 & 34.1 \\
\hline & Female & 50.5 & 69.8 & 61.9 \\
\hline & Not specified & 6.8 & 2.0 & 4.0 \\
\hline & Total & 103 & 149 & 252 \\
\hline \multirow[t]{5}{*}{ Internship duration (months) } & $<3$ & 17.3 & 47.7 & 35.2 \\
\hline & $3-6$ & 39.4 & 26.8 & 32.0 \\
\hline & $6-9$ & 32.7 & 10.7 & 19.8 \\
\hline & $>9$ & 10.6 & 14.8 & 13.0 \\
\hline & Total & 104 & 149 & 253 \\
\hline \multirow[t]{8}{*}{ Areas of internships } & Front office & 20.2 & 12.5 & 15.7 \\
\hline & Food and beverages & 54.8 & 60.4 & 58.1 \\
\hline & Kitchen & 12.5 & .7 & 5.6 \\
\hline & Housekeeping & 11.5 & 21.5 & 17.3 \\
\hline & Human resources & 1.0 & .0 & .4 \\
\hline & Sales and marketing & .0 & 4.9 & 2.8 \\
\hline & Others & 1.0 & 3.5 & 2.4 \\
\hline & Total & 104 & 149 & 253 \\
\hline
\end{tabular}

house-keeping, and general areas such as human resources, and sales and marketing. Of 248 responses, for both groups the main activity was food and beverages (54.8\% and $60.2 \%$ for VET and HE respectively). However, while the next most frequent activity for VET students was the front office (20.2\%) followed by kitchen (12.5\%) and housekeeping (11.5\%), the pattern was somewhat different for HE students with a lesser $12.5 \%$ in the front office, but a higher $21.5 \%$ doing housekeeping.

\section{Views of hospitality workplaces}

The survey responses, by dimension and program, profile of the views of hospitality students towards different facets of hospitality workplaces during their internships (Table 5). Chi square statistics identify significant differences between student groups, by survey statements across seven dimensions. Strengths of relationships are assessed by a Cramer's V statistics on significant relationships.

From the findings, marked differences between the views of the HE participants and the VET participants across all aspects of hospitality workplaces were observed. Notably, on the issues relating to pay/promotion opportunities, management, and commitment to working in the industry, the HE participants appeared less positive than the VET participants. These three dimensions are discussed below (refer to Appendix for full responses to seven dimensions).

The dimension "pay/promotion opportunities" clearly demonstrated strong areas of difference between the two participant groups, with significant differences seen on all eight items of this dimension $(p<.001)$. The participants, on average, showed contrasting views on four items $2,4,5$, and 6 among the eight items, recording statistically significant 
Table 5 Summary of survey responses to three dimensions, showing average agreement (from 1: strongly agree, to 5: strongly disagree) across seven dimensions by student group

\begin{tabular}{|c|c|c|c|c|c|c|c|c|}
\hline \# & Statements & Groups & $\mathbf{n}$ & Mean & SD & $\chi_{4}^{2}$ & $p$ & $V$ \\
\hline \multicolumn{9}{|c|}{ Pay/promotions opportunities } \\
\hline \multirow[t]{2}{*}{1} & \multirow{2}{*}{$\begin{array}{l}\text { I think that the pay for most hospitality jobs not sufficient } \\
\text { to lead a satisfactory life }\end{array}$} & VET & 102 & 3.37 & 1.03 & 42.73 & $.000^{*}$ & .41 \\
\hline & & HE & 147 & 2.57 & .95 & & & \\
\hline \multirow[t]{2}{*}{2} & \multirow{2}{*}{$\begin{array}{l}\text { Considering the long hours and work load I find the pay } \\
\text { low in the hospitality industry }\end{array}$} & VET & 104 & 3.18 & 1.09 & 49.62 & $.000^{*}$ & .45 \\
\hline & & $\mathrm{HE}$ & 148 & 2.27 & .82 & & & \\
\hline \multirow[t]{2}{*}{3} & \multirow[t]{2}{*}{ Promotion is based on merit } & VET & 100 & 1.94 & .60 & 21.64 & $.000^{*}$ & .29 \\
\hline & & $\mathrm{HE}$ & 149 & 2.30 & .91 & & & \\
\hline \multirow[t]{2}{*}{4} & \multirow[t]{2}{*}{ Promotion opportunities are satisfactory } & VET & 100 & 2.15 & .77 & 34.09 & $.000^{*}$ & .37 \\
\hline & & $\mathrm{HE}$ & 149 & 2.79 & .83 & & & \\
\hline \multirow[t]{2}{*}{5} & \multirow{2}{*}{$\begin{array}{l}\text { The opportunity of getting promoted to managerial } \\
\text { positions is limited }\end{array}$} & VET & 100 & 3.16 & 1.08 & 41.29 & $.000^{*}$ & .41 \\
\hline & & $\mathrm{HE}$ & 148 & 2.39 & .84 & & & \\
\hline \multirow[t]{2}{*}{6} & \multirow{2}{*}{$\begin{array}{l}\text { Number of years worked in the industry is taken into } \\
\text { consideration in promotion decisions }\end{array}$} & VET & 89 & 3.10 & 1.15 & 31.10 & $.000^{*}$ & .35 \\
\hline & & $\mathrm{HE}$ & 147 & 2.44 & .89 & & & \\
\hline \multirow[t]{2}{*}{7} & \multirow{2}{*}{$\begin{array}{l}\text { It is very difficult to get promoted if you do not 'have an } \\
\text { uncle in the court' }\end{array}$} & VET & 97 & 3.45 & 1.16 & 44.24 & $.000^{*}$ & .43 \\
\hline & & HE & 149 & 2.62 & .98 & & & \\
\hline \multirow[t]{2}{*}{8} & \multirow[t]{2}{*}{ Promotions are not consistent } & VET & 97 & 3.53 & 1.00 & 47.10 & $.000^{*}$ & .44 \\
\hline & & $\mathrm{HE}$ & 149 & 2.60 & .94 & & & \\
\hline \multicolumn{9}{|c|}{ Managers } \\
\hline \multirow[t]{2}{*}{1} & \multirow[t]{2}{*}{ Managers value to employees } & VET & 99 & 1.95 & .63 & 23.05 & $.000^{*}$ & .31 \\
\hline & & HE & 149 & 2.47 & .91 & & & \\
\hline \multirow[t]{2}{*}{2} & Managers do not make an effort for the organisational & VET & 99 & 3.92 & .60 & 30.50 & $.000^{*}$ & .35 \\
\hline & commitment of employees & $\mathrm{HE}$ & 147 & 3.37 & .84 & & & \\
\hline 3 & Managers delegate authority in order for employees to & VET & 98 & 1.89 & .61 & 22.35 & $.000^{*}$ & .30 \\
\hline & & $\mathrm{HE}$ & 149 & 2.34 & .80 & & & \\
\hline 4 & Most managers do not have an educational background & VET & 101 & 4.03 & 68 & 46.45 & $.000^{*}$ & .43 \\
\hline & & $\mathrm{HE}$ & 147 & 2.63 & .85 & & & \\
\hline 5 & Managers value employees'suggestions & VET & 103 & 2.03 & .75 & 33.60 & $.000^{*}$ & .37 \\
\hline & & $\mathrm{HE}$ & 147 & 2.63 & .85 & & & \\
\hline 6 & Managers do not reward employees who are doing a & VET & 100 & 3.61 & .88 & 17.90 & .001 & \\
\hline & good job & HE & 146 & 3.16 & .89 & & & \\
\hline 7 & Managers behave respectfully to employees & VET & 103 & 1.84 & .60 & 31.89 & $.000^{*}$ & .36 \\
\hline & & $\mathrm{HE}$ & 147 & 2.40 & .86 & & & \\
\hline 8 & Managers make sure that employees participate in deci- & VET & 103 & 2.18 & .82 & 9.62 & .047 & \\
\hline & & HE & 149 & 2.50 & .90 & & & \\
\hline 9 & There is no good relationship between managers and & VET & 103 & 3.73 & .82 & 18.23 & .001 & \\
\hline & & $\mathrm{HE}$ & 149 & 3.28 & .84 & & & \\
\hline 10 & Managers do not help solve employees' personal prob- & VET & 100 & 3.58 & 1.01 & 37.74 & $.000^{*}$ & .39 \\
\hline & & $\mathrm{HE}$ & 147 & 3.05 & .81 & & & \\
\hline 11 & Managers do provide vocational training when necessary & VET & 103 & 1.82 & .70 & 23.70 & $.000^{*}$ & 31 \\
\hline & & $\mathrm{HE}$ & 147 & 3.05 & .81 & & & \\
\hline 12 & Managers behave in a fair way to employees & VET & 104 & 1.98 & .67 & 28.78 & $.000^{*}$ & .34 \\
\hline & & $\mathrm{HE}$ & 148 & 2.55 & .88 & & & \\
\hline 13 & Managers do not put great effort into making employees & VET & 102 & 3.86 & .83 & 33.35 & $.000^{*}$ & .37 \\
\hline & satisfied from their jobs & $\mathrm{HE}$ & 145 & 3.21 & .93 & & & \\
\hline & nitment to the industry & & & & & & & \\
\hline 1 & The disadvantages of working in the hospitality industry & VET & 104 & 3.75 & .79 & 30.31 & $.000^{*}$ & .35 \\
\hline & outweigh the advantages & HE & 149 & 3.07 & .99 & & & \\
\hline
\end{tabular}


Table 5 (continued)

\begin{tabular}{|c|c|c|c|c|c|c|c|c|}
\hline \# & Statements & Groups & $n$ & Mean & SD & $\chi_{4}^{2}$ & $p$ & $v$ \\
\hline \multirow[t]{2}{*}{2} & \multirow{2}{*}{$\begin{array}{l}\text { I am very happy to have chosen hospitality as a vocation } \\
\text { path }\end{array}$} & VET & 104 & 1.90 & .66 & \multirow[t]{2}{*}{29.05} & \multirow[t]{2}{*}{$.000^{*}$} & \multirow[t]{2}{*}{.34} \\
\hline & & HE & 149 & 2.44 & .87 & & & \\
\hline \multirow[t]{2}{*}{3} & \multirow{2}{*}{$\begin{array}{l}\text { I would not want my son or daughter to study hospitality } \\
\text { and work in the hospitality industry }\end{array}$} & VET & 102 & 3.51 & 1.06 & \multirow[t]{2}{*}{12.46} & \multirow[t]{2}{*}{.014} & \\
\hline & & $\mathrm{HE}$ & 149 & 3.15 & 1.05 & & & \\
\hline \multirow[t]{2}{*}{4} & \multirow{2}{*}{$\begin{array}{l}\text { I would like to work in the hospitality industry after } \\
\text { graduation }\end{array}$} & VET & 104 & 3.63 & 1.29 & \multirow[t]{2}{*}{24.55} & \multirow[t]{2}{*}{$.000^{*}$} & .41 \\
\hline & & $\mathrm{HE}$ & 148 & 3.51 & .94 & & & \\
\hline & \multirow{2}{*}{$\begin{array}{l}\text { I will definitely not work in the hospitality industry after } \\
\text { graduation }\end{array}$} & VET & 104 & 3.63 & 1.29 & \multirow[t]{2}{*}{24.55} & \multirow[t]{2}{*}{$.000^{*}$} & .31 \\
\hline & & $\mathrm{HE}$ & 148 & 3.51 & .94 & & & \\
\hline \multirow[t]{2}{*}{6} & \multirow{2}{*}{$\begin{array}{l}\text { I recommend first year students choose a different career } \\
\text { path than hospitality }\end{array}$} & VET & 103 & 3.97 & .89 & \multirow[t]{2}{*}{8.73} & \multirow[t]{2}{*}{.068} & \\
\hline & & $\mathrm{HE}$ & 146 & 3.87 & .91 & & & \\
\hline & \multirow[t]{2}{*}{ It was a mistake to choose hospitality as a career path } & VET & 103 & 4.15 & .73 & \multirow[t]{2}{*}{8.08} & \multirow[t]{2}{*}{.89} & \\
\hline & & $\mathrm{HE}$ & 148 & 3.87 & .91 & & & \\
\hline \multirow[t]{2}{*}{8} & \multirow{2}{*}{$\begin{array}{l}\text { I recommend a job in the hospitality industry to my } \\
\text { friends and relatives because it is very nice to be part of } \\
\text { this industry }\end{array}$} & VET & 103 & 1.94 & .76 & \multirow[t]{2}{*}{40.97} & \multirow[t]{2}{*}{$.000^{*}$} & \multirow[t]{2}{*}{.41} \\
\hline & & $\mathrm{HE}$ & 145 & 2.53 & .79 & & & \\
\hline \multirow[t]{2}{*}{9} & \multirow{2}{*}{$\begin{array}{l}\text { I see my vocational (professional) future in the hospitality } \\
\text { industry }\end{array}$} & VET & 103 & 2.47 & .99 & \multirow[t]{2}{*}{44.51} & \multirow[t]{2}{*}{$.000^{*}$} & \multirow[t]{2}{*}{42} \\
\hline & & $\mathrm{HE}$ & 148 & 3.36 & .94 & & & \\
\hline
\end{tabular}

* Due to Bonferroni correction of multiple testing, significance is tested against $\mathrm{p}<.001$; Effect sizes (Cramer's $\mathrm{V}$ ) based on

Cohen's (1988) guidelines: between .20 and .40 "medium or typical", between .40 and .60 "Iarge or larger than typical"

differences. Thus, looking at items where there was a level of difference in the views, on item 2 'low pay', $65.3 \%$ of the HE participants $(M=2.27)$ were in agreement that the pay was low for long hours of work, while only $31.4 \%$ of the VET participants indicated this view $(M=3.18)$. Another differing response pattern was item 6 'experience-based promotion'. Whereas $59.1 \%$ of the HE participants showed agreement $(M=2.32)$ on the feature of experience-based promotion, i.e., number of years working in the industry taken into consideration for promotion decision making, only $28.1 \%$ of the VET participants expressed a similar view $(M=3.13)$. The HE participants, on average, showed a higher degree of agreement $(M=2.39)$ with promotion being limited in the hospitality industry as opposed to the VET counterparts $(M=3.16)$.

Interestingly, among 10 out of 13 items having significant difference recorded on dimension "managers", whilst the majority of the VET participants $(80.2 \%)$ showed disagreement towards item 4 with regard to most managers having no educational background in hospitality, almost half of the HE participants expressed uncertainty (45.3\%), and $38.7 \%$ expressed an opposite view. Another different response pattern observed on item 10, indicated that whilst $64 \%$ of the VET participants indicated disagreement towards 'managers' not helping employees with personal problems', only $27.9 \%$ of the HE participants expressed this attitude. Similarly, $73.5 \%$ of the VET participants indicated managers put great effort into making sure employees were satisfied with their jobs, as compared to $38.6 \%$ of their HE counterparts.

Looking at "commitment to the industry", the HE and the VET participant groups were significantly different on seven out of ten items. Firstly, $65.4 \%$ of the VET participants were in disagreement that a career in hospitality was outweighed with disadvantages, while only $34.9 \%$ of the HE participants indicated this view. Therefore, hospitality was viewed as being a satisfactory career path by $87.5 \%$ of the VET participants as compared to $59.1 \%$ of the HE participants, and being a promising vocational future perceived by 
$81.6 \%$ of the VET participants $(M=2.47)$ and $48.3 \%$ of the HE participants $(M=3.36)$. Whilst many participants in both groups were uncertain about whether they had a definite plan for working in the hospitality industry, $49.5 \%$ of the VET participants expressed the attitude of being keen on a hospitality job as compared to only $15.5 \%$ of the HE participants displaying a similar attitude.

\section{Assessing significant educational level differences}

A key question from this analysis is whether a different profile for VET and HE students can be identified. Logistic regression was undertaken to identify items that were most predictive of group membership, thus most clearly differentiating the views of HE and VET students. Results, of the significantly differentiating variables, by dimension, are presented in Table 6.

This assessment identified significant factors in all six of the models assessed with odds ratios ranging from those indicating very major differences in the issues on work environment between VET and HE students as discussed below.

Marked differences were seen on "industry-person congeniality" where four of the independent variables made significant contributions to prediction. Notably, of these three had OR below 1 indicating, for example, that for these items HE participants were less likely to agree than VET participants. For these, the level of disagreement of the HE participants can be identified by a reciprocal calculation, thus for the OR of .54 (thus

Table 6 Summary of logistic regression results, by model, of predictors reporting the student group

\begin{tabular}{|c|c|c|c|c|c|c|}
\hline \multirow[t]{2}{*}{$\#$} & \multirow[t]{2}{*}{ Dimension/Statement } & \multirow[t]{2}{*}{ B (SE) } & \multirow[t]{2}{*}{$p$} & \multicolumn{3}{|c|}{$95.0 \% \mathrm{Cl}$ for odds ratio } \\
\hline & & & & Lower & Odds ratio & Upper \\
\hline \multicolumn{7}{|c|}{ Industry-person congeniality } \\
\hline 2 & Personality well suited jobs & $-.61(.21)$ & .004 & .36 & .54 & .82 \\
\hline 5 & Work pleasure & $.63(.21)$ & .003 & 1.24 & 1.87 & 2.84 \\
\hline 7 & Pleased to satisfy customers & $-.54(.27)$ & .042 & .34 & .58 & .98 \\
\hline 9 & Pleased to serve tourists & $-.50(.21)$ & .015 & .41 & .61 & .91 \\
\hline \multicolumn{7}{|c|}{ Pay/promotion opportunities } \\
\hline 4 & Satisfactory promotion & $.70(.28)$ & .011 & 1.18 & 2.02 & 3.46 \\
\hline 6 & ${ }^{R}$ Experience-based promotion & $.46(.20)$ & .023 & 1.07 & 1.58 & 2.35 \\
\hline 8 & ${ }^{R}$ Inconsistent promotion & $.54(.21)$ & .009 & 1.14 & 1.72 & 2.58 \\
\hline \multicolumn{7}{|c|}{ Commitment } \\
\hline 1 & ${ }^{R}$ Outweigh of disadvantages & $.69(.20)$ & .001 & 1.34 & 2.00 & 2.99 \\
\hline 4 & Wanting hospitality work after graduation & $1.198(.32)$ & .000 & 1.80 & 3.31 & 6.10 \\
\hline 5 & ${ }^{R}$ No plan for hospitality work & $-.67(.20)$ & .001 & .35 & .51 & .76 \\
\hline \multicolumn{7}{|c|}{ Co-workers } \\
\hline 4 & Easy making friend with & $-.27(.27)$ & .000 & .17 & .28 & .48 \\
\hline 5 & Easy getting along with & $.85(.27)$ & .002 & 1.38 & 2.34 & 3.98 \\
\hline \multicolumn{7}{|c|}{ Managers } \\
\hline 4 & ${ }^{R}$ With no hospitality background & $.60(.22)$ & .006 & 1.19 & 1.82 & 2.78 \\
\hline \multicolumn{7}{|c|}{ Social status } \\
\hline 3 & Family pride & $.77(.21)$ & .000 & 1.43 & 2.16 & 3.25 \\
\hline
\end{tabular}


reciprocal of 1.85), this can be interpreted as the HE participants being around twice more likely to feel they fit with the job. Similar patterns of findings were found on the three other significant items. For instance, the OR of .58 (reciprocal of 1.72) recorded for item 6 'pleased to satisfy customers' indicates that the HE participants being around twice as likely to please tourists.

The dimension of "pay/promotion opportunities", an important one particularly for those with strong career expectations, also included several relevant issues, with three independent variables ('satisfactory promotion,' 'experience-based promotion', and 'inconsistent promotion'), identified as significant ( $p=.011, p=.023$ and $p=.009)$. These items highlight the stronger longer-term interests of the HE students. For example, in looking at 'satisfactory promotion' the OR of 2.02 indicates that where a participant did not feel that promotion opportunities were satisfactory, they were almost twice as likely to be a HE participant. Similarly, HE students were less likely to feel that number of years worked in the industry should be linked to promotion decisions, or general concerns by HE students about the consistency of promotions in the hospitality.

With respect to "commitment to the industry", three independent variables ('outweigh of disadvantages', 'wanting hospitality work', and 'no plan for hospitality work') were found in this model to make significant contributions to prediction $(p=.001, p=.000$, and $p=.001$, respectively). These items highlight the lack of commitment to the industry of the HE students. For example, the OR value of 2.0 recorded for 'commitment to the industry' suggested that the more a participant agreed that the disadvantages outweighed the advantages in the hospitality industry, two times more likely they were a HE participant. Similarly, the HE students were less likely to indicate their interest in working in the hospitality after graduation.

The results for "co-workers" showed that three of the independent variables made significant contributions to prediction. The first significant predictor 'easy making friend with' ( $p=.000$ ) recorded an OR of .28 (reciprocal of 3.57). This indicates that the more a participant agreed it was easy to make friends with workers in the hospitality industry, over three and a half times more likely they were a VET participant. 'Easy getting along with' was the second significant predictor $(p=.002)$. The OR value of 2.34 indicates that the response to the Likert scale is raised by one point, i.e., the less they agreed that it was easy to get along with people working in the hospitality industry, the participant is over twice as likely to be a HE participant.

Only one independent variable ('with no hospitality background') on the model on "managers" made significant contributions to prediction $(p=.006)$. The predictor recorded an OR of 1.82 suggested that the HE participants were almost twice as likely to be negative about the educational background in hospitality of managers. For "social status", only one of the independent variables, item 1 'family pride' made a significant contribution to the model $(p=.000, O R=2.16)$. This indicates that HE participants were around twice as likely to indicate that their family was proud of their hospitality career.

From this analysis, the identified differences support the development of different profiles of HE and VET students. HE students look to hospitality as a career, one that many see their families as having pride in. They were particularly interested in fair and meritbased promotion opportunities, and were more likely to be critical of current management. Many appeared to have considered their own personal fit with the hospitality 
industry, and where they could assess the benefits of working in the industry long-term outweighed potential disadvantages, they had a stronger long-term commitment. VET students, on the other hand, were generally contented with different aspects of the hospitality workplaces. They were not particularly concerned about but generally satisfied with promotion opportunities in the industry. They perceived themselves to be in good interactions with their co-workers. They therefore expressed a more vested interest in hospitality careers.

\section{Discussion}

Results indicated marked differences between the views of the HE participants and the VET participants on several aspects of hospitality workplaces, including the industryperson congeniality, pay and promotion opportunities, co-workers, managers, and commitment to the hospitality industry.

VET students expressed more positive attitudes towards their experience of working in the hospitality industry. This finding contrasts with previous studies examining college students' views of industry experiences in other countries such as Turkey, the United States, and Australia, which identified a relationship between students' direct experience with the industry, and their negative attitudes towards hospitality jobs (Aksu and Köksal 2005; Kusluvan and Kusluvan 2000; Richardson 2010a). Findings from this study indicate that the results from the VET students align with the view that direct interaction with hospitality industry workplaces leads to more favourable evaluations of careers in the industry (Richardson and Thomas 2012). In contrast, findings indicated that HE students' desire to work in the hospitality industry were decreased after direct interaction with workplaces. This finding aligns with a number of studies investigating the impact of internships on career intentions and motivation to work in the hospitality industry (Busby and Gibson 2010; Divine et al. 2007; Kusluvan et al. 2003). The HE students' resultant low level of commitment to the industry found in this study aligns with other research in the Netherlands and China indicating hospitality students' ambitions for future careers tends to decline as they gain experience, and become aware of the actual circumstances of working in the industry (Blomme et al. 2009; Jenkins 2001; Wang and Huang 2014). These findings suggest that whilst the VET students have more realistic expectations, the HE students have inflated expectations, and poor preparation for workplaces. HE students' low career commitment also confirm previous research indicating the transient nature of hospitality/tourism careers (e.g., Bednarska and Olszewski 2013; Jiang and Tribe 2009; Kusluvan and Kusluvan 2000; Richardson 2010a; Richardson and Butler 2012).

Results of this study highlighted the mismatch between HE students' expectations on entering the industry, and the realities of working in the industry. These findings have been reported in previous studies (Jenkins 2001; O'Leary and Deegan 2005; Raybould and Wilkins 2005), and this mismatch may consequently result in graduates leaving the industry. Dissatisfaction with hospitality workplaces, as a result of unmet expectations, may result in a lack of return on students' investment in education in terms of money, effort and time, with the associated loss of these students from the industry reflecting an inefficient HE system. Thus, labour market entry and HE credentials become an issue for students. Since student expectations may be re-aligned through internships (Harris 
and Zhao 2004), this has important implications for collaborative efforts between the industry and HEIs to enable these expectations to be re-aligned in a positive manner. Students should be adequately prepared at institutions to transition into the hospitality work environment. They should be presented with realistic view of the conditions of working in the industry so that they can accurately envision the benefits and demands of a hospitality career. These findings highlight the need for diverse and realistic career orientations for students if Vietnam is to realise benefits from its investment in HE. It is also important to recognise that students' decisions regarding career choices may change over time (Wang and Huang 2014). In reality, since an individual career choice can be influenced by interactions, turning points and transformations throughout the individual's lifetime (Öhman and Stenlund 2001; Tanova et al. 2008), an awareness of students' perceptions, and understanding students' perspectives towards career decisions, can make those turning points and transformations more positive for the individual, as well as stakeholders involved.

Additionally, HE students in this study expressed concern regarding promotion opportunities in the Vietnamese hospitality industry. They perceived their future chances of being promoted to the managerial level as limited, and reported that they felt mechanisms for promotion lacked consistency in the industry. This appeared likely to impact on their long-term commitment to hospitality as a career. Evidence in this study confirms the phenomenon of limited diffusion of knowledge and skills at the managerial level in multinational hotel enterprises in developing countries (Andriotis 2002; Fortanier and Van Wijik 2010; Kusluvan and Karamustafa 2001). Key management positions are generally outsourced to maintain firm specific advantages (Andriotis 2002; Dunning 1988), and only basic operational level skill personnel are trained locally to assure service quality and performance (Ascher 1985; Dunning 1988; Kusluvan and Karamustafa 2001). Such outsourcing strategies for management positions were found to jeopardise employment opportunities in the local community (Fortanier and Van Wijik 2010; Kusluvan and Karamustafa 2001; Mowforth and Munt 2003). This also limits both potential upskilling for local HE trainees and graduates as they potentially transition from their academic learning environments into industry practice. The situation in the Vietnamese context also aligns with research elsewhere reporting the inability of many HE graduates to apply their knowledge and skills in their workplaces (Elias and Purcell 2004; Keep and Mayhew 2004). This has important implications for a clear differentiation between VET and $\mathrm{HE}$ in terms of academic and professional preparation for students at relevant levels, and confirms the importance of a differentiated career path for VET and HE graduates recognised by the hospitality industry.

HE students' decreased commitment to working in the hospitality industry has important implications for industry employers. The lack of highly skilled and motivated local personnel may have a negative impact on service quality, potentially resulting in negative consequences for customer satisfaction and loyalty, and ultimately impacting on the economic competitiveness of the sector. In addition, without a shift in approach the current practice of outsourcing highly skilled hospitality staff to work in high-end hospitality operations is likely to continue, with associated long-term costs and implications for Vietnam. Interestingly, some research has suggested that increased exposure to hospitality/tourism working environment tends to bring about positive change to student 
commitment to the industry (Bednarska and Olszewski 2013); however, the results of this study indicated that such change is not currently occurring in Vietnam, due to student perceptions of their limited future career paths in the industry.

\section{Conclusion}

Findings from this study indicate differences between VET and HE student interns, and their likely long-term commitment to the hospitality industry, which have major implications for the long-term development of the hospitality industry in Vietnam. While the VET students who were well prepared for lower-level operational roles in the industry, were generally satisfied, different issues were highlighted with the HE students, with long-term retention of this group in the industry found to be questionable.

The results of this study have important implications for various stakeholder groups. Students' negative perceptions, associated with their internship experiences in different aspects of hospitality workplaces, currently appear to result in detrimental consequences for HE students, with many not planning on remaining in the hospitality sector. This has both short-term and long-term implications for hospitality employers, hospitality educational providers, and Vietnam's HE system. These implications result in immediate workforce issues, limiting the higher level skills available in the sector, and also pressures on the HE system to contribute to an increase in the international competitiveness of its sector-thus having implications for government and policy makers.

The sample of tertiary hospitality students in this study was predominantly obtained in Ho Chi Minh City (HCMC), located in South Vietnam. As such, the findings of this study are not generalisable to other populations; however the findings are suggestive of possible patterns in HCMC and other regions across Vietnam as HCMC is considered the educational centre of the country with the most developed private HE sector, where the majority of hospitality HE programs are provided. In addition, student enrolments in these programs are sourced from regions all over Vietnam, thus providing additional evidence to address the scarcity of research in HE in the Vietnamese context. Future empirical studies are recommended to further confirm the validity and reliability of the scale measuring hospitality students' attitudes of hospitality workplaces in the Vietnamese context, on a larger sample.

Authors' contributions

AHL drafted the manuscript; HK provided advice on analyses and edited the methodology and results; and CVM provided advice on and edited the literature and the discussion. All authors read and approved the final manuscript.

Acknowledgements

This research is part of the doctoral research conducted by Dr. Anh Le, under supervision of Dr. Christine McDonald and Dr. Helen Klieve in the School of Education and Professional Studies at Griffith University.

\section{Competing interests}

The authors declare that they have no competing interests. The manuscript or the content of the manuscript has not been published, or submitted for publication elsewhere.

Availability of data and materials

The survey data is available in an SPSS format.

Consent for publication

Survey respondents provided their consent to use of their anonymized data for research purpose.

Ethics approval and consent to participate

This research was approved by the Human Research Ethics Committees of Griffith University and was carried out in accordance with the National Statement on Ethical Conduct in Human Research [EDN/B5/14/HREC]. Permission for the survey scale used and adapted in this study was provided by the survey developer. To gain consent from participants, 
the informed consent information was presented in the introduction page of the online survey to assure the participants that the survey responses were anonymous and confidential, and participants had freedom to decide whether to participate in the research.

Funding

This research has not been funded by any organisations.

\section{Appendix}

See Table 7.

Table 7 Summary of survey responses, showing average agreement (from 1: strongly agree, to 5: strongly disagree) across seven dimensions by student group

\begin{tabular}{|c|c|c|c|c|c|c|c|c|}
\hline \# & Statements & Groups & $\mathrm{n}$ & Mean & SD & $\chi_{4}^{2}$ & $p$ & $v$ \\
\hline \multicolumn{9}{|c|}{ Nature of work } \\
\hline \multirow[t]{2}{*}{1} & \multirow[t]{2}{*}{ I find jobs in the hospitality industry interesting } & VET & 104 & 1.80 & .72 & 11.20 & \multirow[t]{2}{*}{.011} & \\
\hline & & $\mathrm{HE}$ & 148 & 1.99 & .61 & 27.81 & & \\
\hline \multirow[t]{2}{*}{2} & \multirow{2}{*}{$\begin{array}{l}\text { Family life is negatively affected for people working in } \\
\text { the hospitality industry due to the nature of work }\end{array}$} & VET & 104 & 3.39 & 1.24 & \multirow{2}{*}{27.81} & \multirow[t]{2}{*}{$.000^{*}$} & .34 \\
\hline & & HE & 148 & 2.81 & 1.01 & & & \\
\hline \multicolumn{9}{|c|}{ Social status } \\
\hline \multirow[t]{2}{*}{1} & \multirow[t]{2}{*}{ My family is proud of my profession in hospitality } & VET & 104 & 2.13 & .81 & \multirow{2}{*}{21.69} & \multirow[t]{2}{*}{$.000^{*}$} & .29 \\
\hline & & $\mathrm{HE}$ & 147 & 2.63 & .88 & & & \\
\hline \multirow[t]{2}{*}{2} & \multirow{2}{*}{$\begin{array}{l}\text { Working in hospitality is regarded as an important and } \\
\text { beneficial service to the society in Vietnam }\end{array}$} & VET & 104 & 1.98 & .72 & \multirow{2}{*}{6.65} & \multirow[t]{2}{*}{.155} & \\
\hline & & $\mathrm{HE}$ & 145 & 2.18 & .77 & & & \\
\hline \multirow[t]{2}{*}{3} & \multirow{2}{*}{$\begin{array}{l}\text { I talk to my relatives and friends with pride about my } \\
\text { vocation in the hospitality industry }\end{array}$} & VET & 104 & 1.85 & .72 & \multirow[t]{2}{*}{7.53} & \multirow[t]{2}{*}{.110} & \\
\hline & & HE & 145 & 2.07 & .82 & & & \\
\hline \multicolumn{9}{|c|}{ Industry-person congeniality } \\
\hline \multirow[t]{2}{*}{1} & \multirow[t]{2}{*}{ I find serving foreign tourists degrading } & VET & 103 & 4.57 & .65 & \multirow{2}{*}{7.83} & \multirow[t]{2}{*}{.098} & \\
\hline & & HE & 148 & 1.96 & .72 & & & \\
\hline 2 & I am well suited to working in the hospitality industry & VET & 104 & 2.99 & 1.12 & 41.40 & $.000^{*}$ & .41 \\
\hline & & $\mathrm{HE}$ & 149 & 2.28 & .71 & & & \\
\hline 3 & I find serving Vietnamese tourists degrading & VET & 104 & 4.41 & .78 & 11.34 & .023 & \\
\hline & & HE & 149 & 4.29 & .72 & & & \\
\hline 4 & I can use my abilities and skills in hospitality jobs & VET & 97 & 1.84 & .62 & 6.44 & .169 & \\
\hline & & HE & 148 & 1.96 & .72 & & & \\
\hline 5 & I get pleasure while working in the hospitality industry & VET & 103 & 2.11 & .84 & 21.29 & $.000^{*}$ & .41 \\
\hline & & $\mathrm{HE}$ & 148 & 2.55 & .83 & & & \\
\hline 6 & I believe that my moral values will degrade if I work in the & VET & 104 & 4.46 & .71 & 3.84 & .280 & \\
\hline & & HE & 149 & 4.29 & .80 & & & \\
\hline 7 & I like to see satisfied customers when I serve them & VET & 103 & 1.56 & .65 & 3.96 & .266 & \\
\hline & & HE & 147 & 1.43 & .58 & & & \\
\hline 8 & It is not nice to serve people while they are on holiday & VET & 104 & 4.30 & .89 & 19.13 & .001 & \\
\hline & & HE & 146 & 4.02 & .81 & & & \\
\hline 9 & It is a very nice feeling to serve those who are on holiday & VET & 104 & 2.93 & 1.18 & 38.51 & $.000^{*}$ & .39 \\
\hline & & $\mathrm{HE}$ & 149 & 2.32 & .74 & & & \\
\hline & promotions opportunities & & & & & & & \\
\hline 1 & I think that the pay for most hospitality jobs not sufficient & VET & 102 & 3.37 & 1.03 & 42.73 & $.000^{*}$ & .41 \\
\hline & & HE & 147 & 2.57 & .95 & & & \\
\hline 2 & Considering the long hours and work load I find the pay & VET & 104 & 3.18 & 1.09 & 49.62 & $.000^{*}$ & .45 \\
\hline & & HE & 148 & 2.27 & .82 & & & \\
\hline
\end{tabular}


Table 7 (continued)

\begin{tabular}{|c|c|c|c|c|c|c|c|c|}
\hline \# & Statements & Groups & $\mathbf{n}$ & Mean & SD & $\chi_{4}^{2}$ & $p$ & V \\
\hline \multirow[t]{2}{*}{3} & \multirow[t]{2}{*}{ Promotion is based on merit } & VET & 100 & 1.94 & .60 & 21.64 & $.000^{*}$ & .29 \\
\hline & & $\mathrm{HE}$ & 149 & 2.30 & .91 & & & \\
\hline \multirow[t]{2}{*}{4} & \multirow[t]{2}{*}{ Promotion opportunities are satisfactory } & VET & 100 & 2.15 & .77 & 34.09 & $.000^{*}$ & .37 \\
\hline & & $\mathrm{HE}$ & 149 & 2.79 & .83 & & & \\
\hline \multirow[t]{2}{*}{5} & \multirow{2}{*}{$\begin{array}{l}\text { The opportunity of getting promoted to managerial } \\
\text { positions is limited }\end{array}$} & VET & 100 & 3.16 & 1.08 & 41.29 & $.000^{*}$ & .41 \\
\hline & & $\mathrm{HE}$ & 148 & 2.39 & .84 & & & \\
\hline \multirow[t]{2}{*}{6} & \multirow{2}{*}{$\begin{array}{l}\text { Number of years worked in the industry is taken into } \\
\text { consideration in promotion decisions }\end{array}$} & VET & 89 & 3.10 & 1.15 & 31.10 & $.000^{*}$ & .35 \\
\hline & & $\mathrm{HE}$ & 147 & 2.44 & .89 & & & \\
\hline \multirow[t]{2}{*}{7} & \multirow{2}{*}{$\begin{array}{l}\text { It is very difficult to get promoted if you do not 'have an } \\
\text { uncle in the court' }\end{array}$} & VET & 97 & 3.45 & 1.16 & 44.24 & $.000^{*}$ & .43 \\
\hline & & $\mathrm{HE}$ & 149 & 2.62 & .98 & & & \\
\hline \multirow[t]{2}{*}{8} & \multirow[t]{2}{*}{ Promotions are not consistent } & VET & 97 & 3.53 & 1.00 & 47.10 & $.000^{*}$ & .44 \\
\hline & & $\mathrm{HE}$ & 149 & 2.60 & .94 & & & \\
\hline \multicolumn{9}{|c|}{ Co-workers } \\
\hline \multirow[t]{2}{*}{1} & \multirow{2}{*}{$\begin{array}{l}\text { There is no team spirit amongst co-workers in the hospi- } \\
\text { tality industry }\end{array}$} & VET & 101 & 3.08 & 1.17 & 17.44 & .002 & \\
\hline & & $\mathrm{HE}$ & 148 & 3.54 & .90 & & & \\
\hline \multirow[t]{2}{*}{2} & \multirow{2}{*}{$\begin{array}{l}\text { There is cooperation amongst employees in the hospital- } \\
\text { ity industry }\end{array}$} & VET & 101 & 1.86 & .57 & 13.60 & .009 & \\
\hline & & $\mathrm{HE}$ & 147 & 2.16 & .69 & & & \\
\hline \multirow[t]{2}{*}{3} & \multirow{2}{*}{$\begin{array}{l}\text { Employees are generally uneducated in the hospitality } \\
\text { industry }\end{array}$} & VET & 101 & 4.19 & .72 & 14.11 & .007 & \\
\hline & & $\mathrm{HE}$ & 148 & 3.81 & 1.01 & & & \\
\hline \multirow[t]{2}{*}{4} & I can make friends easily with people working in the & VET & 100 & 2.82 & 1.15 & 43.92 & $.000^{*}$ & .42 \\
\hline & & $\mathrm{HE}$ & 149 & 2.03 & .69 & & & \\
\hline 5 & It is not easy to get along with people working in the & VET & 101 & 1.14 & .71 & 19.54 & $.000^{*}$ & .28 \\
\hline & & $\mathrm{HE}$ & 148 & 3.71 & .77 & & & \\
\hline 6 & Most employees are highly motivated and enthusiastic & VET & 98 & 2.33 & .81 & 27.29 & $.000^{*}$ & .33 \\
\hline & & $\mathrm{HE}$ & 146 & 2.87 & .81 & & & \\
\hline 7 & Most people working in the hospitality industry are rude & VET & 101 & 4.41 & .57 & 14.63 & .002 & \\
\hline & & $\mathrm{HE}$ & 148 & 4.07 & .82 & & & \\
\hline 8 & I think there are good relationships amongst employees & VET & 98 & 2.20 & .75 & 26.18 & $.000^{*}$ & .32 \\
\hline & & $\mathrm{HE}$ & 147 & 2.65 & .79 & & & \\
\hline 9 & I find people working in the hospitality industry boring & VET & 99 & 4.10 & .58 & 12.59 & .013 & \\
\hline & & $\mathrm{HE}$ & 149 & 3.82 & .83 & & & \\
\hline & & & & & & & & \\
\hline 1 & Managers value to employees & VET & 99 & 1.95 & .63 & 23.05 & $.000^{*}$ & .31 \\
\hline & & HE & 149 & 2.47 & .91 & & & \\
\hline 2 & Managers do not make an effort for the organisational & VET & 99 & 3.92 & .60 & 30.50 & $.000^{*}$ & .35 \\
\hline & & $\mathrm{HE}$ & 147 & 3.37 & .84 & & & \\
\hline 3 & Managers delegate authority in order for employees to & VET & 98 & 1.89 & .61 & 22.35 & $.000^{*}$ & .30 \\
\hline & & $\mathrm{HE}$ & 149 & 2.34 & .80 & & & \\
\hline 4 & Most managers do not have an educational background & VET & 101 & 4.03 & .68 & 46.45 & $.000^{*}$ & .43 \\
\hline & & $\mathrm{HE}$ & 147 & 2.63 & .85 & & & \\
\hline 5 & Managers value employees'suggestions & VET & 103 & 2.03 & .75 & 33.60 & $.000^{*}$ & .37 \\
\hline & & $\mathrm{HE}$ & 147 & 2.63 & .85 & & & \\
\hline 6 & Managers do not reward employees who are doing a & VET & 100 & 3.61 & .88 & 17.90 & .001 & \\
\hline & & $\mathrm{HE}$ & 146 & 3.16 & .89 & & & \\
\hline 7 & Managers behave respectfully to employees & VET & 103 & 1.84 & .60 & 31.89 & $.000^{*}$ & .36 \\
\hline & & $\mathrm{HE}$ & 147 & 2.40 & .86 & & & \\
\hline 8 & Managers make sure that employees participate in deci- & VET & 103 & 2.18 & .82 & 9.62 & .047 & \\
\hline & & $\mathrm{HE}$ & 149 & 2.50 & .90 & & & \\
\hline
\end{tabular}


Table 7 (continued)

\begin{tabular}{|c|c|c|c|c|c|c|c|c|}
\hline \# & Statements & Groups & n & Mean & SD & $\chi_{4}^{2}$ & $p$ & $v$ \\
\hline \multirow[t]{2}{*}{9} & \multirow{2}{*}{$\begin{array}{l}\text { There is no good relationship between managers and } \\
\text { employees }\end{array}$} & VET & 103 & 3.73 & .82 & 18.23 & .001 & \\
\hline & & HE & 149 & 3.28 & .84 & & & \\
\hline \multirow[t]{2}{*}{10} & \multirow{2}{*}{$\begin{array}{l}\text { Managers do not help solve employees' personal prob- } \\
\text { lems }\end{array}$} & VET & 100 & 3.58 & 1.01 & 37.74 & $.000^{*}$ & .39 \\
\hline & & $\mathrm{HE}$ & 147 & 3.05 & .81 & & & \\
\hline \multirow[t]{2}{*}{11} & \multirow[t]{2}{*}{ Managers do provide vocational training when necessary } & VET & 103 & 1.82 & .70 & 23.70 & $.000^{*}$ & 31 \\
\hline & & $\mathrm{HE}$ & 147 & 3.05 & .81 & & & \\
\hline \multirow[t]{2}{*}{12} & \multirow[t]{2}{*}{ Managers behave in a fair way to employees } & VET & 104 & 1.98 & .67 & 28.78 & $.000^{*}$ & .34 \\
\hline & & HE & 148 & 2.55 & .88 & & & \\
\hline \multirow[t]{2}{*}{13} & \multirow{2}{*}{$\begin{array}{l}\text { Managers do not put great effort into making employees } \\
\text { satisfied from their jobs }\end{array}$} & VET & 102 & 3.86 & .83 & 33.35 & $.000^{*}$ & .37 \\
\hline & & $\mathrm{HE}$ & 145 & 3.21 & .93 & & & \\
\hline \multicolumn{9}{|c|}{ Commitment to the industry } \\
\hline \multirow[t]{2}{*}{1} & \multirow{2}{*}{$\begin{array}{l}\text { The disadvantages of working in the hospitality industry } \\
\text { outweigh the advantages }\end{array}$} & VET & 104 & 3.75 & .79 & 30.31 & $.000^{*}$ & .35 \\
\hline & & $\mathrm{HE}$ & 149 & 3.07 & .99 & & & \\
\hline & \multirow{2}{*}{$\begin{array}{l}\text { I am very happy to have chosen hospitality as a vocation } \\
\text { path }\end{array}$} & VET & 104 & 1.90 & .66 & 29.05 & $.000^{*}$ & .34 \\
\hline & & $\mathrm{HE}$ & 149 & 2.44 & .87 & & & \\
\hline \multirow[t]{2}{*}{3} & \multirow{2}{*}{$\begin{array}{l}\text { I would not want my son or daughter to study hospitality } \\
\text { and work in the hospitality industry }\end{array}$} & VET & 102 & 3.51 & 1.06 & 12.46 & .014 & \\
\hline & & $\mathrm{HE}$ & 149 & 3.15 & 1.05 & & & \\
\hline & \multirow{2}{*}{$\begin{array}{l}\text { I would like to work in the hospitality industry after } \\
\text { graduation }\end{array}$} & VET & 104 & 3.63 & 1.29 & 24.55 & $.000^{*}$ & .41 \\
\hline & & $\mathrm{HE}$ & 148 & 3.51 & .94 & & & \\
\hline & \multirow{2}{*}{$\begin{array}{l}\text { I will definitely not work in the hospitality industry after } \\
\text { graduation }\end{array}$} & VET & 104 & 3.63 & 1.29 & 24.55 & $.000^{*}$ & .31 \\
\hline & & $\mathrm{HE}$ & 148 & 3.51 & .94 & & & \\
\hline & \multirow{2}{*}{$\begin{array}{l}\text { I recommend first year students choose a different career } \\
\text { path than hospitality }\end{array}$} & VET & 103 & 3.97 & .89 & 8.73 & .068 & \\
\hline & & $\mathrm{HE}$ & 146 & 3.87 & .91 & & & \\
\hline & \multirow[t]{2}{*}{ It was a mistake to choose hospitality as a career path } & VET & 103 & 4.15 & .73 & 8.08 & .89 & \\
\hline & & $\mathrm{HE}$ & 148 & 3.87 & .91 & & & \\
\hline \multirow[t]{2}{*}{8} & \multirow{2}{*}{$\begin{array}{l}\text { I recommend a job in the hospitality industry to my } \\
\text { friends and relatives because it is very nice to be part of } \\
\text { this industry }\end{array}$} & VET & 103 & 1.94 & .76 & 40.97 & $.000^{*}$ & .41 \\
\hline & & $\mathrm{HE}$ & 145 & 2.53 & .79 & & & \\
\hline & \multirow{2}{*}{$\begin{array}{l}\text { I see my vocational (professional) future in the hospitality } \\
\text { industry }\end{array}$} & VET & 103 & 2.47 & .99 & 44.51 & $.000^{*}$ & .42 \\
\hline & & $\mathrm{HE}$ & 148 & 3.36 & .94 & & & \\
\hline
\end{tabular}

* Due to Bonferroni correction of multiple testing, significance is tested against $p<.001$; Effect sizes (Cramer's V) based on Cohen's (1988) guidelines: between .20 and .40 "medium or typical", between .40 and .60 "large or larger than typical"

\section{Publisher's Note}

Springer Nature remains neutral with regard to jurisdictional claims in published maps and institutional affiliations.

Received: 16 May 2018 Accepted: 12 December 2018

Published online: 20 December 2018

\section{References}

Aksu AA, Köksal DC (2005) Perceptions and attitudes of tourism students in Turkey. Int J Contemp Hosp Manag 17(5):436-447

Andriotis K (2002) Scale of hospitality firms and local economic development-evidence from Crete. Tour Manag 23(4):333-341

Ascher F (1985) Tourism: transnational corporations and cultural identities. UNECO

Ashwil M (2010) Vietnam a rising star on the US higher education scene. Vietnam: World Education News and Reviews Barron P (1999) The theory and practice of industrial placement: An analysis of hospitality students' experiences. In: CAUTHE 1999: Delighting the Senses; Proceedings from the Ninth Australian Tourism and Hospitality Research Conference, Bureau of Tourism Research, p. 279

Barrows CW, Walsh J (2002) "Bridging the gap" between hospitality management programmes and the private club industry. Int J Contemp Hosp Manag 14(3):120-127 
Bednarska MA, Olszewski M (2013) Students'attitudes towards career in the tourism industry-Implications for tacit knowledge management. J Entrep Manag Innov 9(1):119-134

Beggs B, Ross CM, Goodwin B (2008) A comparison of student and practitioner perspectives of the travel and tourism internship. J Hosp Leisure Sports Tourism Educ 7(1):31

Bell B, Schmidt C (1996) Field practicums: What influence on graduate careers. Pract Exp Prof Educ 20:123-134

Berry WD (1993) Understanding regression assumptions, vol 92. Sage Publications, New York

Bilsland C, Nagy H (2015) Work-Integrated Learning in Vietnam: perspectives of Intern Work Supervisors. Asia Pac J Cooper Educ 16(3):185-198

Blomme R, Van Rheede A, Tromp D (2009) The hospitality industry: an attractive employer? An exploration of students' and industry workers' perceptions of hospitality as a career field. J Hosp Tourism Educ 21(2):6-14

Bodewig C, Badiani-Magnusson R (2014) Skilling up Vietnam: Preparing the workforce for a modern market economy. World Bank Publications, Washington

Brown P, Hesketh A, Williams S (2004) The mismanagement of talent: employability and jobs in the knowledge economy. Oxford University Press, Oxford

Busby GD, Gibson P (2010) Tourism and hospitality internship experiences overseas: a british perspective. J Hosp Leisure Sports Tourism Educ 9(1):4

Cabin RJ, Mitchell RJ (2000) To Bonferroni or not to Bonferroni: When and how are the questions. Bull Ecol Soc Am 81(3):246-248

Chen FC, Ku E, Shyr YH, Chen FH, Chou SS (2009) Job demand, emotional awareness, and job satisfaction in internships: the moderating effect of social support. Soc Behav Personal 37(10):1429-1440

Cohen MP (1998) Determining sample sizes for surveys with data analyzed by hierarchical linear models. J Off Stat 14(3):267

Cook SJ, Parker RS, Pettijohn CE (2004) The perceptions of interns: a longitudinal case study. J Educ Business 79(3):179

Crotti R, Misrahi T (2015) The travel \& tourism competitiveness report 2015: growth through shocks. World Econ Forum, Geneva

Devine F, Baum T, Hearns N, Devine A (2007) Cultural diversity in hospitality work: the Northern Ireland experience. Int J Hum Resource Manag 18(2):333-349

Di Gropello E (2008) Vietnam: Higher education and skills for growth. World Bank Publications, Washington

Di Gropello E (2011) Putting higher education to work: skills and research for growth in East Asia. World Bank Publications, Washington

Do HM, Do QTN (2014) Higher and tertiary education in Vietnam. Higher Education in Vietnam. Palgrave Macmillan, London, pp 29-53

Dunning JH (1988) The theory of international production. Int Trade J 3(1):21-66

Elias P, Purcell K (2004) Researching graduate careers seven years on. ESRU/Warwick (IER)

Fell A, Kuit JA (2003) Placement learning and the code of practice: rhetoric or reality? Active learning in higher education 4(3):214-225

Field A (2013) Discovering statistics using IBM SPSS statistics. Sage Publications, New York

Fligstein N (1996) Markets as politics: A political-cultural approach to market institutions. Am Sociol Rev 25:656-673

Fong LHN, Luk C, Law R (2014) How do hotel and tourism students select internship employers? A segmentation approach. J Hosp Leisure Sport Tourism Educ 15:68-79

Fortanier F, Van Wijk J (2010) Sustainable tourism industry development in sub-Saharan Africa: consequences of foreign hotels for local employment. Int Business Rev 19(2):191-205

Goodman RJ Jr, Sprague LG (1991) The future of hospitality education: meeting the industry's needs. Cornell Hotel Restaurant Admin Q 32(2):66-70

Harris KJ, Zhao J (2004) Industry internships: feedback from participating faculty and industry executives. Int I Contemp Hosp Manag 16(7):429-435

Hiltebeitel KM, Leauby BA, Larkin JM (2000) Job satisfaction among entry-level accountants. CPA J 70(5):76

Institute of International Education [IIE] (2004) Higher education in Vietnam update, May

Jafari J (2002) Tourism education and training models, getting to the core of destination planning and management. TedQual 1:29-34

Jayawardena C (2001) Challenges in international hospitality management education. Int J Contemp Hosp Manag 13(6):310-315

Jenkins AK (2001) Making a career of it? Hospitality students'future perspectives: an Anglo-Dutch study. Int J Contemp Hosp Manag 12(1):13-20

Jiang B, Tribe J (2009) 'Tourism jobs_-Short lived professions': student attitudes towards tourism careers in China. J Hosp Leisure Sport Tourism Educ 9(1):4-19

Ju J, Emenheiser DA, Clayton HR, Reynolds JS (1998) Korean students' perceptions of the effectiveness of their internship experiences in the hospitality industry in Korea. Asia Pac J Tourism Res 3(1):37-44

Kaplowitz MD, Hadlock TD, Levine R (2004) A comparison of web and mail survey response rates. Public Opinion Q 68(1):94-101

Keep E, Mayhew K (2004) The economic and distributional implications of current policies on higher education. Oxford Rev Econ Policy 20(2):298-314

Ketels C, Nguyen DC, Nguyen TTA, Do HH (2010) Vietnam competitiveness report. Central Institute for Economic Management, Hanoi

Korpi T, Mertens A (2004) Training and industrial restructuring: structural change and labour mobility in West Germany and Sweden. Int Jf Manpower 25:90-103

Kusluvan S, Karamustafa K (2001) Multinational hotel development in developing countries: an exploratory analysis of critical policy issues. Int J Tourism Res 3(3):179-197

Kusluvan S, Kusluvan Z (2000) Perceptions and attitudes of undergraduate tourism students towards working in the tourism industry in Turkey. Tourism Manag 21:251-269 
Kusluvan S, Kusluvan Z, Eren D (2003) Undergraduate tourism students' satisfaction with student work experience and its impact on their future career intentions: a case study. Manag Emp Attitudes Behav Tourism Hosp Ind 2003:135-151

Lam T, Ching L (2007) An exploratory study of an internship program: the case of Hong Kong students. Int J Hosp Manag 26(2):336-351

Lam T, Xiao H (2000) Challenges and constraints of hospitality and tourism education in China. Int J Contemp Hosp Manag 12(5):291-295

Le AH, Klieve H, McDonald CV (2015) Transnational tourism programs in Vietnam: students' perspective and a practitioner's reflection. JTourism Hosp Culin Arts 7(1):32-57

Leathwood C, O'connell P (2003) 'It's a struggle': the construction of the 'new student'in higher education. J. Educ Policy 18(6):597-615

Lee SA (2008) Increasing student learning: a comparison of students' perceptions of learning in the classroom environment and their industry-based experiential learning assignments. J Teach Travel Tourism 7(4):37-54

Leslie D, Richardson A (2000) Tourism and cooperative education in UK undergraduate courses: are the benefits being realised? Tourism Manag 21(5):489-498

Littlejohn D, Watson S (2004) Developing graduate managers for hospitality and tourism. Int J Contemp Hosp Manag 16(7):408-414

Maher A (2005) Work experience: the career advantages. In: Twentieth annual placement advisors for tourism and hospitality Conference, London

McHardy P, Allan T (2000) Closing the gap between what industry needs and what higher education provides. Educ Training 42(9):496-508

Mehta A, Felipe J, Quising P, Camingue S (2013) Where have all the educated workers gone? Services and wage inequality in three Asian economies. Metroeconomica 64(3):466-497

Mertler CA (2001) Lessons learned from the administration of a web-based survey. Paper presented at the annual meeting of the Mid-Western Educational Research Association, Chicago, Illinois

Molseed TR, Alsup J, Voyles J (2003) The role of the employer in shaping students' work-related skills. J Emp Counse 40(4):161-171

Morgan GA, Leech NL, Gloeckner GW, Barrett KC (2013) IBM SPSS for introductory statistics: use and interpretation. Routledge, New York

Morrison A, O'Mahony GB (2003) The liberation of hospitality management education. Int J Contemp Hosp Manag 15(1):38-44

Mowforth M, Munt I (2003) Tourism and sustainability: development, globalisation and new tourism in the third world. Routledge, New York

Nguyen H, Chaisawat M (2011) The current situation and future development of hospitality and tourism higher education in Vietnam. J Tourism Hosp Culin Arts 3(2):57-67

Öhman A, Stenlund H (2001) Career choice, professional preferences and gender? The case of Swedish physiotherapy students. Adv physiother 3(3):94-107

O'Leary S, Deegan J (2005) Career progression of Irish tourism and hospitality management graduates. Int J Contemp Hosp Manag 17(5):421-432

Oliver D (2002) The US community college model and Vietnam's higher education system. In: Paper presented at the Texas Tech University Vietnam centre's 4th triennial symposium, Lubbock, Texas.

Petrillose MJ, Montgomery R (1997) An exploratory study of internship practices in hospitality education and industry's perception of the importance of internships in hospitality curriculum. J Hosp Tourism Educ 9(4):46-51

Podolny JM (1993) A status-based model of market competition. Am J Sociol 98:829-872

Raybould M, Wilkins H (2005) Over qualified and under experienced: turning graduates into hospitality managers. Int J Contemp Hosp Manag 17(3):203-216

Reay D, David ME, Ball SJ (2005) Degrees of choice: class, race, gender and higher education. Trentham Books, New York

Richardson S (2009) Undergraduates' perceptions of tourism and hospitality as a career choice. Int J Hosp Manag 28:382-388

Richardson S (2010a) Generation Y's perceptions and attitudes towards a career in tourism and hospitality. J Hum Resourc Hosp Tourism 9(2):179-199

Richardson S (2010b) Tourism and hospitality students' perceptions of a career in the industry: a comparison of domestic (Australian) students and international students studying in Australia. J Hosp Tourism Manag 17:1-11

Richardson S, Butler G (2012) Attitudes of Malaysian tourism and hospitality students towards a career in the industry Asia Pac J Tourism Res 17(3):262-276

Richardson S, Thomas NJ (2012) Utilising generation Y: united States hospitality and tourism students' perceptions of careers in the industry. J Hosp Tourism Manag 19(1):102-114

Rothwell A, Arnold J (2007) Self-perceived employability: development and validation of a scale. Personnel Rev 36(1):23-41

Rothwell A, Herbert I, Rothwell F (2008) Self-perceived employability: construction and initial validation of a scale for university students. J Voc Behav 73(1):1-12

Rothwell A, Jewell S, Hardie M (2009) Self-perceived employability: investigating the responses of post-graduate students. J Voc Behav 75(2):152-161

Shariff NM (2013) Reforming hospitality education to fulfil the industry expectations: a case of Universiti Utara Malaysia. Acad Res Int 4(2):243-251

Shin SH, Lee TJ (2011) Degree of motivation of international hospitality students in their work place. J Hosp Leisure Sports Tourism Educ 10(1):135-144

Sills SJ, Song C (2002) Innovations in survey research: an application of web-based surveys. Soc Sci Comput Rev 20(1):22-30

Singh A, Dutta K (2010) Hospitality internship placements: analysis for United Kingdom and India. J Serv Res 10(1):85-99

Smith G, Cooper C (2000) Competitive approaches to tourism and hospitality curriculum design. J Travel Res 39(1):90-95 
Tabachnick BG, Fidell LS, Osterlind SJ (2001) Using Multivariate Statistics. Allyn and Bacon, Boston

Tanova C, Karataş-Özkan M, Inal G (2008) The process of choosing a management career: evaluation of gender and contextual dynamics in a comparative study of six countries: Hungary, Israel, North Cyprus, Turkey, UK and the USA. Career Dev Int 13(4):291-305

Tesone DV, Ricci P (2005) Attributes of entry-level employees: hospitality and tourism managers seeking more than knowledge and skills. J Appl Manag Entrepren 10(2):3-10

Tomlinson M (2008) Graduate employability and student attitudes and orientations to the labour market. J Educ Work 20(4):285-304

Tran TT (2015) Is graduate employability the'whole-of-higher-education-issue'? J Educ Work 28(3):207-227

Trinh THM (2008) Education association between universities and enterprises in Vietnam. J Econ Law Vietnam Natl Univ Hanoi 24:30-34

Truong Q (2006) Human resource management in Vietnam. In: Nankervis A, Chatterjee S, Coffey J (eds) Perspectives of human resource management in the Asia Pacific. Pearson, Sydney

Velde C, Cooper T (2000) Students' perspectives of workplace learning and training in vocational education. Education Training 42(2):83-92

Vietnam National Administration of Tourism [VNAT] (2004) Report on tourism human resource training in recent years and direction, tasks and key solutions by 2010. Hanoi

Vietnam National Administration of Tourism [VNAT] (2006) Vietnam human resources development in tourism program up to 2015. http://vietnamtourism.gov.vn/english/index.php/items/10782

Walo M (1999) The latest win-win strategy in recruiting hotel staff. Hotel Management 12(7):32-33

Walo M (2001) Assessing the contribution of internship in developing Australian tourism and hospitality students' management competencies. Asia Pac J Cooper Educ 2(2):12-28

Wang S, Huang X (2014) College students' perceptions of tourism careers in China: implications for the industry and education providers. J Hum Resourc Hosp Tourism 13(3):211-233

World Tourism Organisation (2004) WTO recommendations to governments for supporting and/or establishing national certification systems for sustainable tourism. Available at http://www.world-tourism.org/sustainable/doc/certificat ion-gov-recomm.pdf

Yiu M, Law R (2012) A review of hospitality internship: different perspectives of students, employers, and educators. J Teach Travel Tourism 12(4):377-402

Zagonari F (2009) Balancing tourism education and training. Int J Hosp Manag 28(1):2-9

Zopiatis A, Constanti P (2007) "And never the twain shall meet": investigating the hospitality industry-education relationship in Cyprus. Education Training 49(5):391-407

\section{Submit your manuscript to a SpringerOpen ${ }^{\circ}$ journal and benefit from:}

- Convenient online submission

- Rigorous peer review

- Open access: articles freely available online

- High visibility within the field

Retaining the copyright to your article

Submit your next manuscript at $\boldsymbol{\nabla}$ springeropen.com 